Article

\title{
Hydraulic and Photosynthetic Traits Vary with Successional Status of Woody Plants on the Loess Plateau
}

\author{
Qiulong Yin ${ }^{1}{ }^{\mathbb{D}}$, Jingwen $\mathrm{He}^{1}$, Tingting Tian ${ }^{1}$, Jiaxin Quan ${ }^{1}$, Peng Zhao ${ }^{1}$, Yongfu Chai ${ }^{1}$, \\ Lei Wang ${ }^{2}$ and Ming Yue ${ }^{1, *}$ \\ 1 Key Laboratory of Resource Biology and Biotechnology in Western China, Northwest University, \\ Xi'an 710069, China; yinq11988@163.com (Q.Y.); hejingw1994@163.com (J.H.); tttstart@163.com (T.T.); \\ jiaxinquan007@163.com (J.Q.); 201631695@stumail.nwu.edu.cn (P.Z.); chaiyongfu@nwu.edu.cn (Y.C.) \\ 2 School of Environment, Nanjing Normal University, Nanjing 210023, China; wanglei.ko@foxmail.com \\ * Correspondence: yueming@nwu.edu.cn
}

Received: 4 March 2019; Accepted: 10 April 2019; Published: 11 April 2019

\begin{abstract}
Research highlights: Water transport and $\mathrm{CO}_{2}$ diffusion are two important processes that determine the $\mathrm{CO}_{2}$ assimilation efficiency in leaves. The integration of leaf economic and hydraulic traits will help to present a more comprehensive view of the succession of woody plants in arid regions. However, studies on hydraulic traits of plants from different successional stages are still rare compared to that on economic traits in arid regions. Materials and methods: We selected 31 species from shrub stage, pioneer tree stage and late successional stage on the Loess Plateau, and measured five economic traits and five hydraulic traits of these species. Results: We found species from the pioneer tree stage exhibited "fast-growing" characteristics with high maximum net photosynthesis rate $\left(P_{\max }\right)$ and vein density $(\mathrm{VD})$. Species from the late successional stage exhibited "slow-growing" characteristics with low $\mathrm{P}_{\max }$ and VD. Economic traits showed no significant differences among the three stages except for $P_{\max }$. Hydraulic traits, such as VD, leaf area to sapwood area ratio and vessel frequency, exhibited significant differences among different stages. Conclusions: Hydraulics may play an important role in the succession of woody plants in arid regions. Hydraulic traits and $\mathrm{P}_{\max }$, should be combined to investigate succession of woody plants in future studies. The "fast-growing" characteristics of pioneer trees and "slow-growing" characteristics of late successional trees may induce the succession of woody plants.
\end{abstract}

Keywords: functional trait; drought tolerance; leaf hydraulics; global change; water relations; community succession

\section{Introduction}

The majority of the Earth's forests are currently undergoing secondary succession [1]. A deeper understanding of the mechanisms that drive succession could help mitigate the losses of biodiversity and ecosystem function [2].

Trait-based approaches are helping to deepen our understanding of the mechanisms that drive community assembly and successional dynamics [3]. Utilizing a trait-based approach would allow researchers to address successional drivers at multiple ecological scales and lead to new insights that integrate ecological systems [4,5]. Plant functional traits are key biological characteristics to classify plant groups according to their responses to environmental factors [6-8]. Among various traits, those related to light capture and carbon economy have received most attention and form the leaf economic traits, such as leaf maximum photosynthetic capacity, leaf dry mass per area and leaf nitrogen concentration [9]. Other groups of traits related to water demand and supply form 
the hydraulic traits [10], such as vein density, vessel frequency and vessel diameter. Studies on the trade-offs of different functional traits might be instructive to the prediction of species replacement, species abundance and distribution along succession, and provide guidelines for forest management and rebuilding [11-14].

A number of studies on economic traits have suggested that species from early stages exhibit high leaf nitrogen concentration, specific leaf area, growth rate and net photosynthesis rate but short leaf life span, while species from advanced stages exhibit opposite characteristics [15-17]. Obvious patterns of these traits have been found between the herbaceous stage and the woody stage as well as among different herbaceous stages (annual herb stage, perennial Artemisia stage and perennial grass stage) on the Loess Plateau [18]. However, the patterns of these traits among different woody stages (shrub stage, pioneer tree stage and late successional stage) have not been found. Economic traits of woody plants from different successional stages exhibit no conspicuous differences [18]. This indicates that economic traits may not be sufficient to investigate the succession of woody plants in arid regions.

Hydraulic traits, which describe the ability of water transport, have been reported to represent a major determinant of plant competitive ability, productivity, mortality and species distribution [19-23]. Some studies on tropical and subtropical forests have found that species from early stages tend to have higher hydraulic conductivity and greater resistance to drought than those from advanced stages of subtropical forests $[17,24]$. However, studies on hydraulic traits of plants from different successional stages are still rare in arid regions. Furthermore, water transport and $\mathrm{CO}_{2}$ diffusion are two important processes that determine the $\mathrm{CO}_{2}$ assimilation efficiency in leaves [25]. However, the relationships between economic and hydraulic traits remain controversial. Li et al. [10] reported that these two sets of traits were decoupled in five tropical-subtropical forests. In contrast, we found that these two sets of traits are coupled in arid regions [26]. Therefore, the integration of economic and hydraulic traits will help to present a more comprehensive view of the succession of woody plants in arid regions.

Here, we test the roles that hydraulic traits and economic traits play in the succession of woody plants in arid regions. We analyzed ten traits across 31 angiosperms from three successional stages including anatomical, physiological and morphological traits on the Loess Plateau, which is famous for arid and uneven precipitation [27]. Specially, we selected five economic traits including leaf thickness (LT), maximum net photosynthesis rate $\left(\mathrm{P}_{\max }\right)$, leaf dry matter content (LDMC), leaf dry mass per area (LMA), and leaf nitrogen concentration per mass (N). In addition, five hydraulic traits were analyzed, including vein density (VD), leaf water potential at turgor loss point (TLP), leaf area to sapwood area ratio $\left(A_{L} / A_{S}\right)$, vessel frequency $(V F)$ and hydraulically weighted diameter $\left(D_{h}\right)$ in branch. Specially, VD determines the water transport efficiency of leaves [28]; TLP is related to drought tolerance of plants [29]; $A_{L} / A_{S}$ is related to the hydraulic efficiency of leaves and the xylem tensions of branches [30]. Furthermore, we selected two branch traits, $D_{h}$ and VF, to increase the dimensionality of traits. These two traits could represent the trade-off between hydraulic efficiency and hydraulic safety [31].

We hypothesized that (1) species from different successional stages exhibit different traits to acclimate to the environmental shifts during forest succession (2) pioneer trees possess "fast-growing" characteristics, while species from the late successional stage may possess "slow-growing" characteristics.

\section{Materials and Methods}

\subsection{Study Site}

The study was carried out in the Ziwuling Forest Region $\left(35^{\circ} 09^{\prime} \mathrm{N}, 108^{\circ} 45^{\prime} \mathrm{E}\right)$, in the middle of the Loess Plateau, Shaanxi Province, China. The climate is semiarid, temperate, continental monsoon, with a mean annual temperature of $9-11^{\circ} \mathrm{C}$ [32]. The mean annual precipitation is $c .560 \mathrm{~mm}$ and mostly occurs in July, August and September. The natural vegetation has been changed due to the changing climate and anthropogenic interference. Further, the denuded lands have been abandoned to forest succession [2]. According to Zhu [33] and Yue [34], stage one (15-50 years) of woody plants is 
dominated by shrubs. Up to stage two (50-100 years), pioneer trees represent the prominent growth. Finally, species in the genus Quercus dominate the late successional stage ( $>100$ years). Quercus wutaishanica forest is the natural late successional vegetation in this region [35]. A set of 10 plots was established and surveyed in the study area during June to August 2016, assigned to three woody successional stages, comprising four $20 \mathrm{~m} \times 20 \mathrm{~m}$ plots for shrub stage $\left(0-10 \mathrm{~cm}\right.$ soil N $1.37 \mathrm{mg} \mathrm{g}^{-1}$, $\left.\mathrm{P} 0.30 \mathrm{mg} \mathrm{g}^{-1}\right)$, three $20 \mathrm{~m} \times 20 \mathrm{~m}$ plots for pioneer tree stage $\left(0-10 \mathrm{~cm}\right.$ soil $\mathrm{N} 1.67 \mathrm{mg} \mathrm{g}^{-1}, \mathrm{P} 0.18 \mathrm{mg}$ $\mathrm{g}^{-1}$; stand density 1050 trees ha $\left.{ }^{-1}\right)$ and three $20 \mathrm{~m} \times 20 \mathrm{~m}$ plots for late successional stage $(0-10 \mathrm{~cm}$ soil N $2.32 \mathrm{mg} \mathrm{g}^{-1}$, P $0.28 \mathrm{mg} \mathrm{g}^{-1}$; stand density 892 trees ha ${ }^{-1}$ ).

\subsection{Species Selection and Sampling}

Samples were collected from 31 woody deciduous species belonging to 26 genera and 14 families (Table 1, Table S1). All sample collection and field experiments were carried out from June to August 2016. The species selected are common and abundant for different successional stages in the study area. For each species, at least 3-4 individuals (in habitats with similar light conditions) were sampled and 8-10 leaves were taken from three branches of each individual. All leaves and branches were collected using a long-reach pruner from the upper sunny part of the canopy. Once collected, three leaves per individual were immediately put into a formalin-acetic-alcohol (FAA) solution for analyses of venation traits. Other leaves were preserved in plastic bags with moist filter papers for analyses of economic traits except for photosynthesis rates measured in situ. 8-10 terminal branches were cut at the base from the upper sunlit part of the canopy of three to four individuals for each species in the early morning, with ends put into water, sealed in black plastic bags and transported immediately to the laboratory for water potential measurements.

Table 1. List of 31 woody species tested in the present study.

\begin{tabular}{|c|c|c|c|c|c|c|}
\hline $\begin{array}{c}\text { Successional } \\
\text { Stages }\end{array}$ & Latin Name & Code & Family Name & $\begin{array}{l}\text { Plant } \\
\text { Functional } \\
\text { Type }\end{array}$ & $\begin{array}{l}\text { Number of } \\
\text { Sampled } \\
\text { Individuals }\end{array}$ & $\begin{array}{l}\text { Mean Canopy } \\
\text { (Sampling) } \\
\text { Height }\end{array}$ \\
\hline \multirow[t]{14}{*}{ Shrub stage } & Corylus heterophylla Fisch. & $\mathrm{Ch}$ & Betulaceae & shrub & 4 & $0.5 \mathrm{~m}(0.5 \mathrm{~m})$ \\
\hline & Cotinus coggygria Scop. & $\mathrm{Cc}$ & Anacardiaceae & shrub & 4 & $1 \mathrm{~m}(1 \mathrm{~m})$ \\
\hline & Cotoneaster melanocarpus Lodd. & $\mathrm{Cm}$ & Rosaceae & shrub & 4 & $2.5 \mathrm{~m}(2.5 \mathrm{~m})$ \\
\hline & Grewia biloba G. Don & $\mathrm{Gb}$ & Tiliaceae & $\begin{array}{l}\text { shrub, small } \\
\text { tree }\end{array}$ & 4 & $1.5 \mathrm{~m}(1.5 \mathrm{~m})$ \\
\hline & Lespedeza bicolor Turcz. & $\mathrm{Lb}$ & Fabaceae & shrub & 4 & $1.5 \mathrm{~m}(1.5 \mathrm{~m})$ \\
\hline & $\begin{array}{l}\text { Lonicera fragrantissima Lindl. \& J. } \\
\text { Paxton }\end{array}$ & Lf & Caprifoliaceae & shrub & 4 & $0.8 \mathrm{~m}(0.8 \mathrm{~m})$ \\
\hline & Lonicera hispida Pall. ex Schult. & Lh & Caprifoliaceae & shrub & 4 & $1 \mathrm{~m}(1 \mathrm{~m})$ \\
\hline & Ostryopsis davidiana Decne. & Od & Betulaceae & shrub & 4 & $1 \mathrm{~m}(1 \mathrm{~m})$ \\
\hline & Periploca sepium Bunge & Ps & Asclepiadaceae & shrub & 4 & $1.2 \mathrm{~m}(1.2 \mathrm{~m})$ \\
\hline & Rhamnus utilis Decne. & $\mathrm{Ru}$ & Rhamnaceae & $\begin{array}{l}\text { shrub, small } \\
\text { tree }\end{array}$ & 4 & $0.8 \mathrm{~m}(0.8 \mathrm{~m})$ \\
\hline & Rosa hugonis Hemsl. & $\mathrm{Rh}$ & Rosaceae & shrub & 4 & $0.6 \mathrm{~m}(0.6 \mathrm{~m})$ \\
\hline & Sophora davidii (Franch.) Skeels & $\mathrm{Sd}$ & Fabaceae & shrub & 4 & $1.6 \mathrm{~m}(1.6 \mathrm{~m})$ \\
\hline & Viburnum betulifolium Batalin & $\mathrm{Vb}$ & Caprifoliaceae & shrub & 4 & $2.3 \mathrm{~m}(2.3 \mathrm{~m})$ \\
\hline & Ziziphus jujuba Mill. & $\mathrm{Zj}$ & Rhamnaceae & $\begin{array}{l}\text { shrub, small } \\
\text { tree }\end{array}$ & 4 & $0.4 \mathrm{~m}(0.4 \mathrm{~m})$ \\
\hline \multirow[t]{10}{*}{$\begin{array}{l}\text { Pioneer tree } \\
\text { stage }\end{array}$} & $\begin{array}{l}\text { Amygdalus davidiana (Carriére) de } \\
\text { Vos ex L. Henry }\end{array}$ & $\mathrm{Ad}$ & Rosaceae & tree & 4 & $2.5 \mathrm{~m}(2.5 \mathrm{~m})$ \\
\hline & Armeniaca sibirica (L.) Lam. & As & Rosaceae & $\begin{array}{l}\text { shrub, small } \\
\text { tree }\end{array}$ & 4 & $3 \mathrm{~m}(3 \mathrm{~m})$ \\
\hline & Betula platyphylla Sukaczev & $\mathrm{Bp}$ & Betulaceae & tree & 4 & $10 \mathrm{~m}(8 \mathrm{~m})$ \\
\hline & Malus baccata (L.) Borkh. & $\mathrm{Mb}$ & Rosaceae & tree & 4 & $4 \mathrm{~m}(4 \mathrm{~m})$ \\
\hline & Populus davidiana Dode & $\mathrm{Pd}$ & Salicaceae & tree & 3 & $8 \mathrm{~m}(7 \mathrm{~m})$ \\
\hline & Populus hopeiensis Hu \& H.F.Chow & $\mathrm{Ph}$ & Salicaceae & tree & 3 & $6 \mathrm{~m}(5 \mathrm{~m})$ \\
\hline & Populus simonii Carr. & Psi & Salicaceae & tree & 3 & $6 \mathrm{~m}(5 \mathrm{~m})$ \\
\hline & Pyrus betulifolia Bunge & $\mathrm{Pb}$ & Rosaceae & tree & 4 & $5 \mathrm{~m}(5 \mathrm{~m})$ \\
\hline & Rhus potaninii Maxim. & $\mathrm{Rp}$ & Anacardiaceae & tree & 4 & $3 \mathrm{~m}(3 \mathrm{~m})$ \\
\hline & Ulmus bergmanniana C.K. Schneid. & $\mathrm{Ub}$ & Ulmaceae & tree & 4 & $3 \mathrm{~m}(3 \mathrm{~m})$ \\
\hline
\end{tabular}


Table 1. Cont.

\begin{tabular}{|c|c|c|c|c|c|c|}
\hline $\begin{array}{l}\text { Successional } \\
\text { Stages }\end{array}$ & Latin Name & Code & Family Name & $\begin{array}{l}\text { Plant } \\
\text { Functional } \\
\text { Type }\end{array}$ & $\begin{array}{l}\text { Number of } \\
\text { Sampled } \\
\text { Individuals }\end{array}$ & $\begin{array}{l}\text { Mean Canopy } \\
\text { (Sampling) } \\
\text { Height }\end{array}$ \\
\hline \multirow{7}{*}{$\begin{array}{l}\text { Late } \\
\text { successional } \\
\text { stage }\end{array}$} & Acer davidii Franch. & Ada & Aceraceae & tree & 4 & $4.5 \mathrm{~m}(4.5 \mathrm{~m})$ \\
\hline & Acer ginnala Maxim. & $\mathrm{Ag}$ & Aceraceae & tree & 4 & $2.5 \mathrm{~m}(2.5 \mathrm{~m})$ \\
\hline & Carpinus cordata Blume. & Cco & Betulaceae & tree & 4 & $3 \mathrm{~m}(3 \mathrm{~m})$ \\
\hline & Cornus walteri Wangerin & $\mathrm{Cw}$ & Cornaceae & tree & 4 & $3.5 \mathrm{~m}(3.5 \mathrm{~m})$ \\
\hline & Diospyros lotus L. & $\mathrm{Dl}$ & Ebenaceae & tree & 4 & $3 \mathrm{~m}(3 \mathrm{~m})$ \\
\hline & Quercus aliena Blume & $\mathrm{Qa}$ & Fagaceae & tree & 3 & $10 \mathrm{~m}(8 \mathrm{~m})$ \\
\hline & Quercus wutaishanica Mayr & Qw & Fagaceae & tree & 3 & $9.5 \mathrm{~m}(8 \mathrm{~m})$ \\
\hline
\end{tabular}

\subsection{Economic Traits}

A photograph of each fresh leaf surface was taken with a digital camera, and leaf surface area (LA, $\mathrm{cm}^{-2}$ ) was measured with Motic Images Plus 2.0 (Motic China, Xiamen, China) software. All leaves were then placed in a drying oven for $72 \mathrm{~h}$ at $70{ }^{\circ} \mathrm{C}$ to determine the dry mass. Leaf dry mass per area (LMA, $\mathrm{g} \mathrm{m}^{-2}$ ) was calculated as the ratio of dry mass to LA. Leaf dry matter content (LDMC, $\mathrm{mg} \mathrm{g}^{-1}$ ) was calculated as the ratio of dry mass to fresh mass [36]. Leaf thickness (LT, mm) was measured through transverse sections using Image-Pro Plus 6.0 (Media Cybernetics, Rockville, MA, USA), avoiding the influence of major veins. For each section, 10-20 measurements were made. The leaf mass-based nitrogen concentrations $\left(\mathrm{N}, \mathrm{mg} \mathrm{g}^{-1}\right)$ were determined using an elemental analyzer (Euro Vector EA3000, Milan, Italy).

Net photosynthesis rates of mature and fully expanded leaves were measured between 9:00-11:00 with the portable photosynthesis system (Li-6400, Li-Cor, Lincoln, NE, USA). $\mathrm{CO}_{2}$ concentration was that of the ambient air and the flow rate was set at $500 \mu \mathrm{mol} \mathrm{s}^{-1}$. Light was provided with an LED and the photosynthetically active radiation (PAR) gradients were 1800, 1500, 1200, 1000, 800, 600, 400, 200, 100, 50, 20 and $0 \mu \mathrm{mol} \mathrm{m}^{-2} \mathrm{~s}^{-1}$ [18]. The response curve of net photosynthesis rate to PAR was fitted

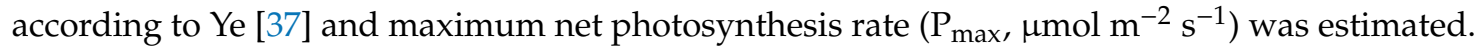

\subsection{Hydraulic Traits}

Leaf vein measurements were performed according to the general protocols described by Brodribb and Jordan [38], with modifications in the present study. A sample of approximately $1 \mathrm{~cm}^{2}$ was excised from the leaf and placed in $10 \%$ sodium hydroxide aqueous solution for several hours to several days, until the minor veins were exposed. Then each sample was soaked in distilled water and stained in 1\% toluidine blue for 30-60 seconds. Finally, the samples were mounted onto glass slides and photographed under a light microscope. The vein length was measured manually by drawing lines along the veins by using Image-Pro Plus 6.0. Vein density (VD, $\mathrm{mm} \mathrm{mm}^{-2}$ ) was calculated as the total length of leaf veins per leaf area. VD was averaged from more than 20 randomly selected fields of view (c. $2.05 \mathrm{~mm}^{2}$ ).

Leaf water potential at turgor loss point (TLP, MPa) was derived from the leaf pressure-volume relationships according to Zhu et al. [17]. Branch ends were re-cut underwater and rehydrated until leaf water potential exceeded $-0.05 \mathrm{MPa}$. Leaves were first weighed to obtain the initial fresh mass and then immediately placed in a pressure chamber (SEC3115, Santa Barbara, CA, USA) to determine the initial water potential. Leaf weight and water potential were measured periodically during slow desiccation of the sample in the laboratory. Finally, leaves were oven-dried for $72 \mathrm{~h}$ at $70{ }^{\circ} \mathrm{C}$ to determine the dry weight. TLP was determined by a pressure-volume relationship analysis program developed by Schulte and Hinckley [39].

Leaf area to sapwood area ratio $\left(\mathrm{A}_{\mathrm{L}} / \mathrm{A}_{\mathrm{S}}, \mathrm{m}^{2} \mathrm{~cm}^{-2}\right)$ was calculated as the ratio of leaf area attached per unit sapwood cross-section area [20]. Total leaf area of leaves distal to the base was measured by the same method as the individual leaves, and the diameter of sapwood was measured with a vernier caliper [36].The vessel frequency $\left(\mathrm{VF}, \mathrm{mm}^{-2}\right)$ and hydraulically weighted diameter $\left(D_{h}, \mu \mathrm{m}\right)$ were 
determined from the terminal branches used for $A_{L} / A_{S}$ estimates (see below for further explanations). Considering that the vessels size changed along the tree stem and branch axis [40,41], subsamples of $2 \mathrm{~cm}$ in length were taken from the base of each branch. Then these samples were immersed for a few seconds in glycerin and cross-sections $(20-40 \mu \mathrm{m})$ of the adaxial ends were cut with a microtome (Leica RM 2235, Leica, Wetzlar, Germany) to make sure the cut-off points of different species were similar. These transverse sections were mounted in glycerin on glass slides and photographed on a microscope. In each image, we measured individual vessel areas and counted the total number of vessels by using Image-Pro Plus 6.0 to estimate the mean vessel area (A) and number of vessels per unit area (VF). Vessel diameter $(D)$ was calculated from the individual vessel area $\left(D=(4 A / \pi)^{1 / 2}\right)$. We calculated the hydraulically weighted diameter $\left(D_{h}, \mu \mathrm{m}\right)$, defined as: $D_{h}=\left(\Sigma D^{4} / n\right)^{1 / 4}$, where $n$ is the total number of vessels [42].

\subsection{Statistical Analysis}

Differences in leaf traits among different successional stages were tested with one-way ANOVA, and the Fisher LSD test was used for post-hoc analysis by using the STATISTICA 10.0 software (Statsoft, Tulsa, OK, USA). Relationships between pairwise traits were analyzed with Pearson's correlation, using zero-mean transformed values of the means of traits to meet the normality assumption. Relationships between pairwise traits were also calculated with phylogenetically independent contrasts (PICs) to evaluate whether the observed traits associations were the result of repeated evolutionary divergences, by using the "analysis of traits" (AOT) module in Phylocom version 4.1 [43]. Phylogenetic tree of the 31 species was generated based on the Angiosperm Phylogeny Group III classification of angiosperm (Figure S1). Multivariate associations of 10 traits on the set of 31 species were analyzed with a principal component analysis (PCA) in CANOCO software for Windows 4.5 (Microcomputer Power, Ithaca, NY, USA), by using zero-mean transformed values of the means of traits to meet the normality assumption.

\section{Results}

Plants from pioneer trees stage exhibited significantly higher $P_{\max }$ compared to those from shrub stage and late successional stage (Figure 1b). Other economic traits showed no significant differences among the three successional stages. Furthermore, species from the pioneer tree stage showed significantly higher VD and VF than species from the late successional stage (Figure 1f,j). $A_{L} / A_{S}$ exhibited a significantly increasing pattern in the order of shrub stage, pioneer tree stage and late successional stage (Figure $1 \mathrm{~g}$ ). In addition, TLP and $\mathrm{D}_{\mathrm{h}}$ showed no significant differences among three successional stages (Figure 1h,i).

Pearson correlation analysis indicated that VD was positively related to $\mathrm{P}_{\max }$, LMA and LT (Table 2). A positive correlation was found between TLP and LDMC according to PICs. $A_{L} / A_{S}$ showed negative correlations with LT, LMA and VD using original data and negative correlations with LDMC, LMA and VD according to PICs. VF was negatively related to $\mathrm{D}_{\mathrm{h}}$. However, these two branch traits showed no significant correlations with leaf traits. 


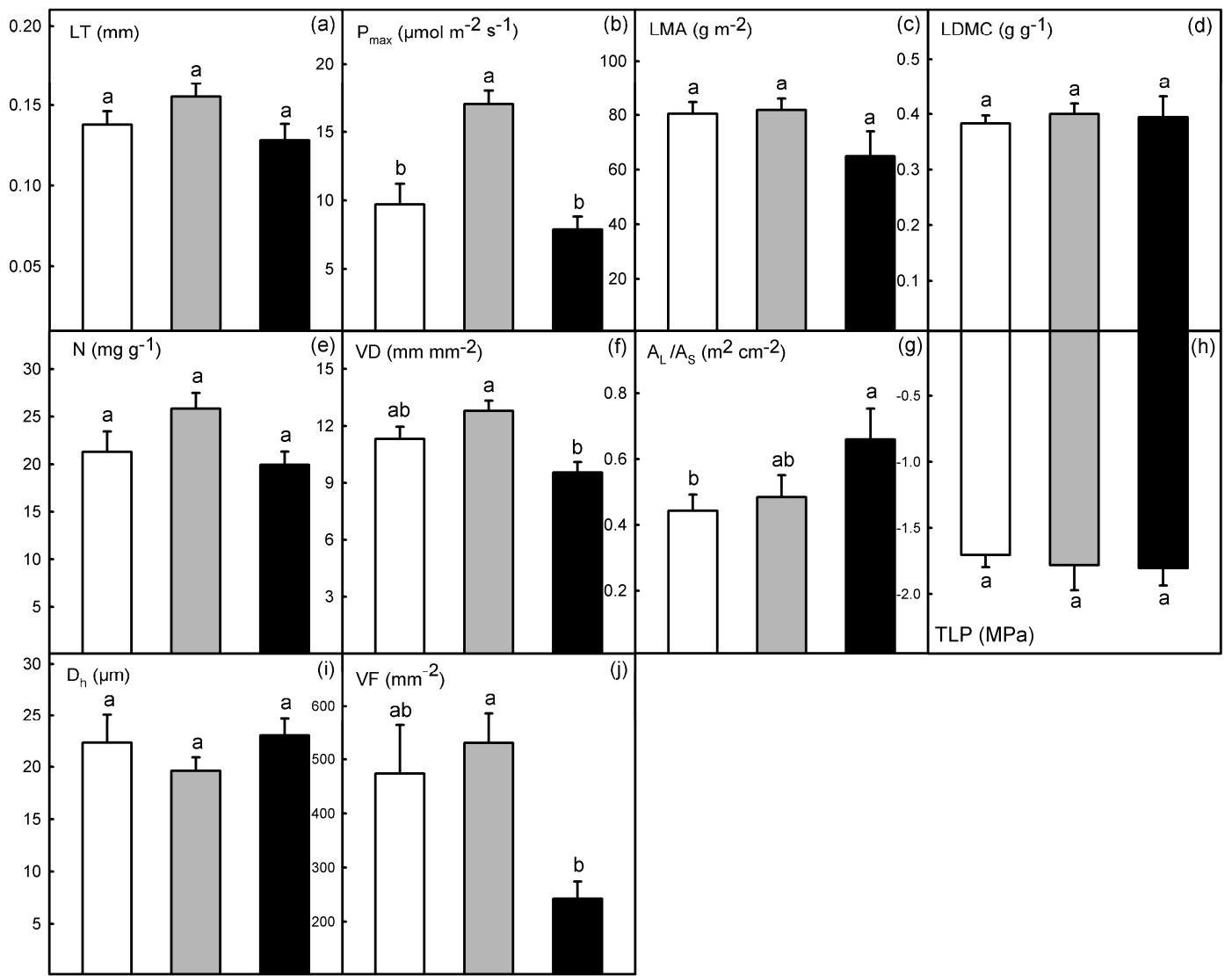

Figure 1. Differences in (a-e) economic traits and $(\mathbf{f}-\mathbf{j})$ hydraulic traits of woody plants among the shrub stage (white columns), pioneer tree stage (grey columns) and late successional stage (black columns). Error bars represent $1 \mathrm{SE}$ and different letters denote significant differences among different stages $\left(P<0.05\right.$, ANOVA). Trait abbreviations: LT (leaf thickness), $\mathrm{P}_{\max }$ (maximum net photosynthesis rate), LDMC (leaf dry matter content), LMA (leaf dry mass per area), $\mathrm{N}$ (leaf nitrogen concentration per mass), VD (vein density), TLP (leaf water potential at turgor loss point), $A_{L} / A_{S}$ (leaf area to sapwood area ratio), $\mathrm{VF}$ (vessel frequency), and $\mathrm{D}_{\mathrm{h}}$ (hydraulically weighted diameter).

Table 2. Pearson correlation coefficients (lower diagonal) and phylogenetically independent contrasts (upper diagonal) among 10 leaf traits.

\begin{tabular}{|c|c|c|c|c|c|c|c|c|c|c|}
\hline & LT & $P_{\max }$ & LDMC & LMA & $\mathbf{N}$ & VD & TLP & $\mathbf{A}_{\mathrm{L}} / \mathbf{A}_{\mathbf{S}}$ & VF & $D_{h}$ \\
\hline LT & & -0.02 & -0.30 & 0.21 & 0.09 & 0.47 * & 0.13 & -0.13 & -0.19 & 0.05 \\
\hline$P_{\max }$ & 0.26 & & 0.18 & $0.43 *$ & $0.44 *$ & 0.40 & -0.14 & -0.28 & 0.20 & 0.18 \\
\hline LDMC & -0.28 & 0.05 & & $0.58 * *$ & -0.30 & 0.31 & $-0.44 *$ & $-0.58 * *$ & 0.35 & -0.30 \\
\hline LMA & 0.41 * & 0.31 & 0.28 & & -0.06 & $0.56 * *$ & -0.23 & $-0.75 * *$ & 0.32 & -0.21 \\
\hline $\mathrm{N}$ & 0.33 & $0.41 *$ & -0.30 & 0.01 & & 0.15 & 0.19 & 0.09 & -0.38 & 0.33 \\
\hline VD & $0.52 * *$ & $0.55^{* *}$ & 0.14 & $0.45 *$ & 0.30 & & -0.16 & $-0.59 * *$ & 0.05 & 0.11 \\
\hline TLP & 0.13 & 0.00 & -0.32 & -0.01 & 0.17 & -0.04 & & 0.13 & 0.00 & 0.03 \\
\hline $\mathrm{A}_{\mathrm{L}} / \mathrm{A}_{\mathrm{S}}$ & $-0.47^{* *}$ & -0.24 & -0.07 & $-0.72 * *$ & -0.04 & $-0.49 * *$ & -0.23 & & -0.14 & 0.07 \\
\hline VF & -0.06 & 0.31 & 0.25 & 0.34 & -0.32 & 0.09 & 0.01 & -0.20 & & $-0.79 * *$ \\
\hline$D_{h}$ & 0.17 & 0.03 & -0.28 & -0.23 & 0.26 & 0.08 & 0.00 & 0.07 & $-0.73^{* *}$ & \\
\hline
\end{tabular}

Significant correlations (in bold) are denoted by asterisks: ${ }^{*}, p<0.05 ;{ }^{* *}, p<0.01$. Trait abbreviations: LT (leaf thickness), $\mathrm{P}_{\max }$ (maximum net photosynthesis rate), LDMC (leaf dry matter content), LMA (leaf dry mass per area), $\mathrm{N}$ (leaf nitrogen concentration per mass), VD (vein density), TLP (leaf water potential at turgor loss point), $A_{L} / A_{S}$ (leaf area to sapwood area ratio), $\mathrm{VF}$ (vessel frequency), and $\mathrm{D}_{\mathrm{h}}$ (hydraulically weighted diameter).

Principal component analysis indicated that PCA axis 1, accounting for $29.77 \%$ of the total variation, showed strong loadings on LT, $\mathrm{P}_{\max }$, LMA, VD and $\mathrm{A}_{\mathrm{L}} / \mathrm{A}_{\mathrm{S}}$ (Figure 2a, Table S2). PCA axis 2, accounting for $23.57 \%$ of the total variation, showed strong loadings on LDMC, N, VF, $\mathrm{D}_{\mathrm{h}}$ (Figure $2 \mathrm{a}$, 
Table S2). Plants from pioneer tree stage (except for Betula platyphylla) and late successional stage were separated well along PCA axis 1 (Figure $2 b$ ). B. platyphylla possesses a much higher $A_{L} / A_{S}$ than other plants from the pioneer tree stage and the second highest across all the 31 species (Table S1). This may induce the separation of B. platyphylla with other plants from the pioneer tree stage. Plants from the shrub stage were not separated from those at the pioneer tree stage and late successional stage along PCA axis 1 (Figure 2b). This may be because that traits of plants from shrub stage varied within a wide range (Table S1), exhibiting the functional diversity of shrubs. Plants cannot be separated along PCA axis 2 (Figure $2 b$ ), showing that LDMC, N, VF and $D_{h}$ may not be key factors underlying species replacement along forest succession in arid regions.
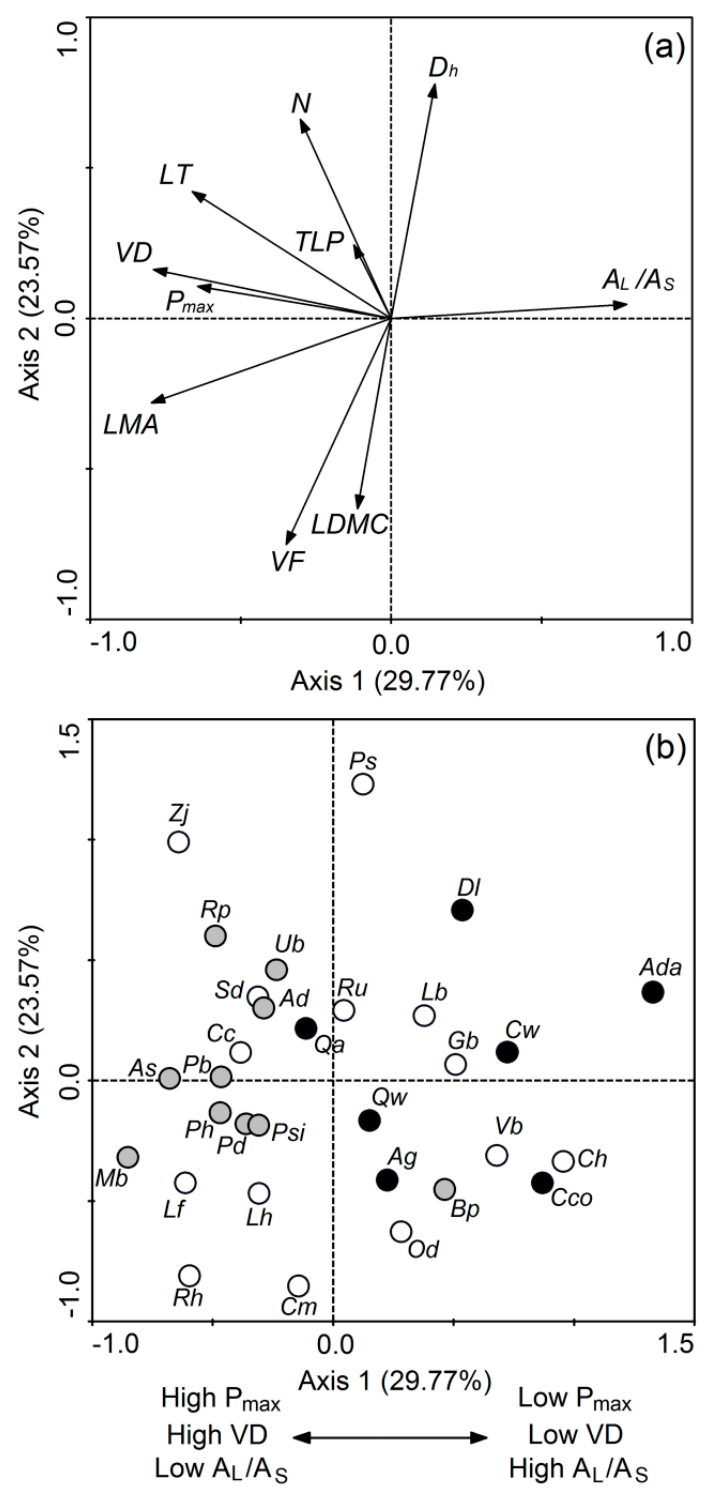

Figure 2. Principal component analysis for 10 traits (a) and 31 woody species (b) for the first two axes. Open, grey and solid circles indicate species from shrub stage, pioneer tree stage and late successional stage, respectively. Trait abbreviations: LT (leaf thickness), $\mathrm{P}_{\max }$ (maximum net photosynthesis rate), LDMC (leaf dry matter content), LMA (leaf dry mass per area), $\mathrm{N}$ (leaf nitrogen concentration per mass), VD (vein density), TLP (leaf water potential at turgor loss point), $A_{L} / A_{S}$ (leaf area to sapwood area ratio), VF (vessel frequency), and $D_{h}$ (hydraulically weighted diameter). The abbreviations for species are provided in Table 1. 


\section{Discussion}

\subsection{Differences of Economic and Hydraulic Traits among Different Successional Stages}

In the present study, plants from pioneer tree stage had significantly higher $\mathrm{P}_{\max }$ compared to those from shrub stage and late successional stage (Figure 1). In general, plants from pioneer tree stage show high growth rate [17], allowing them to rise from the shrub layer and occupy the canopy. The strong photosynthetic capacity is necessary to supplement the carbon cost for high growth rate [44]. Thus, pioneer trees exhibited the highest $P_{\max }$ among three successional stages. However, other economic traits showed no significant differences among three successional stages (Figure 1), which were consistent with the previous study on a few dominant species in this region [18]. This shows that $\mathrm{P}_{\max }$ may play a more important role than other economic traits in the succession of woody plants in arid regions.

Furthermore, pioneer trees exhibited higher VD and VF than plants from late successional stage (Figure 1). This may be due to the highest $\mathrm{P}_{\max }$ of pioneer trees. We found $\mathrm{P}_{\max }$ showed significantly positive correlation with VD. This indicated the correlations between economic traits and hydraulics. For terrestrial plants, the ability of leaves to maintain high photosynthetic rate while avoiding desiccation is the greatest biophysical barrier to carbon gain and ultimately survival [45-47]. To replenish the water lost from open stomata, an efficient water supply is indispensable which is correlated with high VD $[28,38,48,49]$. VD has considerable effects on hydraulic pathlength and bundle sheath surface area [50,51], thus VD is vital in determining water transport efficiency $[28,38,52]$. Therefore, pioneer trees retained higher VD than plants from other stages to replenish the water lost from open stomata induced by high $\mathrm{P}_{\max }$. Moreover, wide vessel diameters are important for achieving the high levels of water transport efficiency [53], while many narrow vessels are safer than a few wide vessels [20,31,54]. However, vessel diameters exhibited no significant differences among different successional stages, while pioneer trees showed significantly higher VF than late successional trees. It shows that pioneer trees may possess both high efficiency and safety to maintain the high growth rate.

In addition, we found $A_{L} / A_{S}$ showed a significantly increasing pattern in the order of successional stages. This was consistent with the increasing soil moisture along the succession trajectory. There is strong evidence that $A_{L} / A_{S}$ plays a vital role in the water relations of plants [55-57]. Decreased $A_{L} / A_{S}$ could increase hydraulic efficiency and reduce the xylem tensions required to supply evaporative area with water [30]. Moreover, TLP is a key trait in assessing drought tolerance among species and biomes [58], but we did not find significant differences of TLP among three successional stages. When we compared our results with those of a study conducted on 34 woody species in south China (mean annual total precipitation c. $1900 \mathrm{~mm}$ ) [17], an 8.7\% lower TLP was found in the present study. This indicated that plants from arid regions were more resistant to desiccation than plants from humidity regions. It seems that the low TLP might be necessary all across the arid habitats of the Loess Plateau. On the other hand, all of the 31 species are deciduous. They can escape harsh conditions by shedding leaves so that they possess similar drought tolerance ability.

\subsection{Strategies of Different Successional Stages: Growth vs. Survival}

Studies on growth-survival trade-offs have been conducted to assess plants performance in different light environments [59-61]. Light-demanding species that occupy forest gaps, possessing high specific leaf area and strong photosynthetic capacity, grow quickly in high-level light environments but die quickly if overtopped and shaded [60,61]. In contrast, shade-tolerant species that occupy understory, possessing low specific leaf area and weak photosynthetic capacity, have high survival rates but limited growth rates $[60,61]$. This trade-off allows plants to adapt to different light environments, but it is not well understood in arid conditions.

We found the trade-offs between growth and survival could be used to explain the succession of woody plants in the present study. Survival is the main priority for plants in arid regions so that 
plants enhance their drought tolerance ability and increase their survival rates, even with a decrease in hydraulic efficiency and growth rates [62]. We found traits that showed no significant differences were mainly for drought tolerance, including LT, LMA, LDMC and TLP. These traits help plants to maintain high survival rates on the Loess Plateau.

On the other hand, pioneer trees possess high growth rates so that they could occupy the upper canopy and obtain sufficient light. Along axis 1, species from the pioneer tree stage exhibited "fast-growing" characteristics, such as high $\mathrm{P}_{\max }$ and VD and low $\mathrm{A}_{\mathrm{L}} / \mathrm{A}_{\mathrm{S}}$. These traits help pioneer trees win the competition with shrubs. In general, pioneer trees are light-demanding species. They grow quickly in high-level light environments but die quickly in shade environment [60,61]. Therefore, pioneer trees are finally replaced by trees from the late successional stage. Late successional species are mainly shade-tolerant species. They have high survival rates but low growth rates understory [60,61]. Along axis 1, species from the late successional stage exhibited "slow-growing" characteristics with low $\mathrm{P}_{\max }$ and VD and high $\mathrm{A}_{\mathrm{L}} / \mathrm{A}_{\mathrm{S}}$. Due to their high survival rates in shade environments, late successional trees win the competition with pioneer trees after slow growth for a long time.

\section{Conclusions}

Our results highlighted that hydraulic capacity played an important role in the succession of woody plants on the Loess Plateau. $P_{\max }$ was more effective than other economic traits for estimating the succession of woody plants. Hydraulic traits and $\mathrm{P}_{\max }$ should be combined to investigate succession in the future. Species from the pioneer tree stage exhibited "fast-growing" characteristics with high photosynthetic and hydraulic capacity, while species from late successional stage exhibited "slow-growing" characteristics with low photosynthetic and hydraulic capacity. In addition, species from the shrub stage showed a wide range of characteristics from "fast-growing" to "slow-growing", exhibiting the functional diversity of shrubs. The trade-offs between growth and survival may induce the succession of woody plants on the Loess Plateau.

Supplementary Materials: The following are available online at http://www.mdpi.com/1999-4907/10/4/327/s1, Table S1: Mean values of 10 traits for 31 woody species, Table S2: Loading scores of 10 traits in the PCA among 31 woody species, Figure S1: Phylogenetic relationships of the 31 species in this study.

Author Contributions: Conceptualization, Q.Y. and M.Y.; Data Curation, Q.Y. and J.H.; Investigation, T.T., J.H., L.W., J.Q. and P.Z.; Methodology, Y.C., and Q.Y.; Project administration, M.Y.; Writing-Original Draft, Q.Y.; Writing-Review and Editing, M.Y.; Funding acquisition, M.Y. and Y.C.

Funding: The study was supported by the National Natural Science Foundation of China (grant No. 41871036, No.31700348 and No. 41571500) and National Special Program on Basic Works for Science and Technology of China (2015FY1103003-6).

Acknowledgments: We are grateful to Zi-Piao Ye from Jinggangshan University for the help in analyzing of photosynthesis data.

Conflicts of Interest: The authors declare no conflict of interest.

\section{References}

1. FAO. Global Forest Resources Assessment: How Are the World's Forests Changing? Food and Agriculture Organization of the United Nations: Rome, Italy, 2015.

2. Chai, Y.; Yue, M.; Wang, M.; Xu, J.; Liu, X.; Zhang, R.; Wan, P. Plant functional traits suggest a change in novel ecological strategies for dominant species in the stages of forest succession. Oecologia 2016, 180, 771-783. [CrossRef] [PubMed]

3. Muscarella, R.; Uriarte, M.; Aide, T.M.; Erickson, D.L.; Forero-Montaña, J.; Kress, W.J.; Swenson, N.G.; Zimmerman, J.K. Functional convergence and phylogenetic divergence during secondary succession of subtropical wet forests in Puerto Rico. J. Veg. Sci. 2016, 27, 283-294. [CrossRef]

4. Ali, A.; Yan, E.R. Functional identity of overstorey tree height and understorey conservative traits drive aboveground biomass in a subtropical forest. Ecol. Indic. 2017, 83, 158-168. [CrossRef]

5. Meiners, S.J.; Cadotte, M.W.; Fridley, J.D.; Pickett, S.T.A.; Walker, L.R. Is successional research nearing its climax? New approaches for understanding dynamic communities. Funct. Ecol. 2015, 29, 154-164. [CrossRef] 
6. Garnier, E.; Cortez, J.; Billès, G.; Navas, M.L.; Roumet, C.; Debussche, M.; Laurent, G.; Blanchard, A.; Aubry, D.; Bellmann, A. Plant functional markers capture ecosystem properties during secondary succession. Ecology 2004, 85, 2630-2637. [CrossRef]

7. Lavorel, S.; Landsberg, J.; Forbes, T.M.S. Plant functional classifications: From general groups to specific groups based on response to disturbance. Trends Ecol. Evol. 1997, 12, 474-478. [CrossRef]

8. Targetti, S.; Messeri, A.; Staglianò, N.; Argenti, G. Leaf functional traits for the assessment of succession following management in semi-natural grasslands: A case study in the North Apennines, Italy. Appl. Veg. Sci. 2013, 16, 325-332. [CrossRef]

9. Wright, I.J.; Reich, P.B.; Westoby, M.; Ackerly, D.D.; Baruch, Z.; Bongers, F.; Cavenderbares, J.; Chapin, F.S.; Cornelissen, J.H.C.; Diemer, M. World-wide leaf economics spectrum. Nature 2004, 428, 821-827. [CrossRef] [PubMed]

10. Li, L.; McCormack, M.L.; Ma, C.; Kong, D.; Zhang, Q.; Chen, X.; Zeng, H.; Niinemets, Ü.; Guo, D. Leaf economics and hydraulic traits are decoupled in five species-rich tropical-subtropical forests. Ecol. Lett. 2015, 18, 899-906. [CrossRef] [PubMed]

11. Coley, P.D.; Bryant, J.P. Resource availability and plant antiherbivore defense. Science 1985, 230, 895-899.

12. Mcgill, B.J.; Enquist, B.J.; Weiher, E.; Westoby, M. Rebuilding community ecology from functional traits. Trends Ecol. Evol. 2006, 21, 178-185. [CrossRef] [PubMed]

13. Poorter, L. Leaf traits show different relationships with shade tolerance in moist versus dry tropical forests. New. Phytol. 2009, 181, 890-900. [CrossRef] [PubMed]

14. Uriarte, M.; Lasky, J.R.; Boukili, V.K.; Chazdon, R.L. A trait-mediated, neighbourhood approach to quantify climate impacts on successional dynamics of tropical rainforests. Funct. Ecol. 2016, 30, 157-167. [CrossRef]

15. Kazakou, E.; Garnier, E.; Navas, M.L.; Roumet, C.; Collin, C.; Laurent, G. Components of nutrient residence time and the leaf economics spectrum in species from Mediterranean old-fields differing in successional status. Funct. Ecol. 2007, 21, 235-245. [CrossRef]

16. Navas, M.L.; Ducout, B.; Roumet, C.; Richarte, J.; Garnier, J.; Garnier, E. Leaf life span, dynamics and construction cost of species from Mediterranean old-fields differing in successional status. New Phytol. 2003, 159, 213-228. [CrossRef]

17. Zhu, S.D.; Song, J.J.; Li, R.H.; Ye, Q. Plant hydraulics and photosynthesis of 34 woody species from different successional stages of subtropical forests. Plant Cell Environ. 2013, 36, 879-891. [CrossRef]

18. Chai, Y.; Liu, X.; Yue, M.; Guo, J.; Wang, M.; Wan, P.; Zhang, X.; Zhang, C. Leaf traits in dominant species from different secondary successional stages of deciduous forest on the Loess Plateau of northern China. Appl. Veg. Sci. 2015, 18, 50-63. [CrossRef]

19. Brodribb, T.J.; Feild, T.S. Leaf hydraulic evolution led a surge in leaf photosynthetic capacity during early angiosperm diversification. Ecol. Lett. 2010, 13, 175-183. [CrossRef]

20. Cosme, L.H.; Schietti, J.; Costa, F.R.; Oliveira, R.S. The importance of hydraulic architecture to the distribution patterns of trees in a central Amazonian forest. New Phytol. 2017, 215, 113-125. [CrossRef] [PubMed]

21. Nardini, A.; Luglio, J. Leaf hydraulic capacity and drought vulnerability: Possible trade-offs and correlations with climate across three major biomes. Funct. Ecol. 2014, 28, 810-818. [CrossRef]

22. Oliveira, R.S. Can hydraulic traits be used to predict sensitivity of drought-prone forests to crown decline and tree mortality? Plant Soil 2013, 364,1-3. [CrossRef]

23. Zhu, S.D.; Chen, Y.J.; Fu, P.L.; Cao, K.F.; Goldstein, G. Different hydraulic traits of woody plants from tropical forests with contrasting soil water availability. Tree Physiol. 2017, 37, 1469-1477. [CrossRef]

24. Mcculloh, K.A.; Meinzer, F.C.; Sperry, J.S.; Lachenbruch, B.; Voelker, S.L.; Woodruff, D.R.; Domec, J.C. Comparative hydraulic architecture of tropical tree species representing a range of successional stages and wood density. Oecologia 2011, 167, 27-37. [CrossRef]

25. Flexas, J.; Scoffoni, C.; Gago, J.; Sack, L. Leaf mesophyll conductance and leaf hydraulic conductance: An introduction to their measurement and coordination. J. Exp. Bot. 2013, 64, 3965-3981. [CrossRef] [PubMed]

26. Yin, Q.; Wang, L.; Lei, M.; Dang, H.; Quan, J.; Tian, T.; Chai, Y.; Yue, M. The relationships between leaf economics and hydraulic traits of woody plants depend on water availability. Sci. Total Environ. 2018, 621, 245-252. [CrossRef] [PubMed]

27. Kou, M.; Jiao, J.; Yin, Q.; Wang, N.; Wang, Z.; Li, Y.; Yu, W.; Wei, Y.; Yan, F.; Cao, B. Successional trajectory over 10 years of vegetation restoration of abandoned slope croplands in the Hill-Gully Region of the Loess Plateau. Land Degrad. Dev. 2016, 27, 919-932. [CrossRef] 
28. Sack, L.; Scoffoni, C. Leaf venation: Structure, function, development, evolution, ecology and applications in the past, present and future. New Phytol. 2013, 198, 983-1000. [CrossRef] [PubMed]

29. Zhu, S.D.; Chen, Y.J.; Ye, Q.; He, P.C.; Liu, H.; Li, R.H.; Fu, P.L.; Jiang, G.F.; Cao, K.F. Leaf turgor loss point is correlated with drought tolerance and leaf carbon economics traits. Tree Physiol. 2018, 38, 658-663. [CrossRef]

30. Martínez-Vilalta, J.; Cochard, H.; Mencuccini, M.; Sterck, F.; Herrero, A.; Korhonen, J.F.J.; Llorens, P.; Nikinmaa, E.; Nolè, A.; Poyatos, R.; et al. Hydraulic adjustment of Scots pine across Europe. New Phytol. 2009, 184, 353-364. [CrossRef]

31. Pratt, R.B.; Jacobsen, A.L. Conflicting demands on angiosperm xylem: Tradeoffs among storage, transport and biomechanics. Plant Cell Environ. 2017, 40, 897-913. [CrossRef]

32. Chai, Y.; Yue, M.; Liu, X.; Guo, Y.; Wang, M.; Xu, J.; Zhang, C.; Chen, Y.; Zhang, L.; Zhang, R. Patterns of taxonomic, phylogenetic diversity during a long-term succession of forest on the Loess Plateau, China: Insights into assembly process. Sci. Rep. 2016, 6, 27087. [CrossRef] [PubMed]

33. Zhu, Z.C. Recovering succession of vegetation in forest region of north Shaanxi Loess Plateau. J. Northwest For. Univ. 1993, 8, 87-94.

34. Yue, M. Division of successional phase in the Platycladus orientalis forest in the South Loess Plateau of the Northern Shanxi Province. Acta Phytoecol. Sinica 1998, 22, 327-335.

35. Wang, S.; Wang, X.; Hua, G.; Fan, W.; Lv, H.; Duan, R. Distinguishing the importance between habitat specialization and dispersal limitation on species turnover. Ecol. Evol. 2013, 3, 3545-3553. [CrossRef]

36. Pérez-Harguindeguy, N.; Díaz, S.; Garnier, E.; Lavorel, S.; Poorter, H.; Jaureguiberry, P.; Bret-Harte, M.S.; Cornwell, W.K.; Craine, J.M.; Gurvich, D.E.; et al. New handbook for standardised measurement of plant functional traits worldwide. Aust. J. Bot. 2013, 61, 167-234. [CrossRef]

37. Ye, Z.P. A new model for relationship between irradiance and the rate of photosynthesis in Oryza sativa. Photosynthetica 2007, 45, 637-640. [CrossRef]

38. Brodribb, T.J.; Jordan, G.J. Water supply and demand remain balanced during leaf acclimation of Nothofagus cunninghamii trees. New Phytol. 2011, 192, 437-448. [CrossRef]

39. Schulte, P.J.; Hinckley, T.M. A comparison of pressure-volume curve data analysis techniques. J. Exp. Bot. 1985, 36, 1590-1602. [CrossRef]

40. Anfodillo, T.; Carraro, V.; Carrer, M.; Fior, C.; Rossi, S. Convergent tapering of xylem conduits in different woody species. New Phytol. 2006, 169, 279-290. [CrossRef]

41. Carrer, M.; von Arx, G.; Castagneri, D.; Petit, G. Distilling allometric and environmental information from time series of conduit size: The standardization issue and its relationship to tree hydraulic architecture. Tree Physiol. 2015, 35, 27-33. [CrossRef] [PubMed]

42. Tyree, M.T.; Zimmermann, M.H. Hydraulic architecture of whole plants and plant performance. In Xylem Structure and the Ascent of Sap; Springer: Berlin/Heidelberg, Germany, 2002; pp. 175-214.

43. Webb, C.O.; Donoghue, M.J. Phylomatic: Tree assembly for applied phylogenetics. Mol. Ecol. Resour. 2005, 5, 181-183. [CrossRef]

44. Li, Y.; Liu, C.; Zhang, J.; Yang, H.; Xu, L.; Wang, Q.; Sack, L.; Wu, X.; Hou, J.; He, N. Variation in leaf chlorophyll concentration from tropical to cold-temperate forests: Association with gross primary productivity. Ecol. Indic. 2018, 85, 383-389. [CrossRef]

45. Mitchell, P.J.; O'Grady, A.P.; Tissue, D.T.; White, D.A.; Ottenschlaeger, M.L.; Pinkard, E.A. Drought response strategies define the relative contributions of hydraulic dysfunction and carbohydrate depletion during tree mortality. New Phytol. 2013, 197, 862-872. [CrossRef] [PubMed]

46. Simonin, K.A.; Limm, E.B.; Dawson, T.E. Hydraulic conductance of leaves correlates with leaf lifespan: Implications for lifetime carbon gain. New Phytol. 2012, 193, 939-947. [CrossRef] [PubMed]

47. Zwieniecki, M.A.; Boyce, C.K. Evolution of a unique anatomical precision in angiosperm leaf venation lifts constraints on vascular plant ecology. Proc. R. Soc. B 2014, 281, 20132829. [CrossRef]

48. Brodribb, T.J.; Holbrook, N.M.; Gutiérrez, M.V. Hydraulic and photosynthetic co-ordination in seasonally dry tropical forest trees. Plant Cell Environ. 2002, 25, 1435-1444. [CrossRef]

49. Xiong, D.; Flexas, J.; Yu, T.; Peng, S.; Huang, J. Leaf anatomy mediates coordination of leaf hydraulic conductance and mesophyll conductance to $\mathrm{CO}_{2}$ in Oryza. New Phytol. 2017, 213, 572-583. [CrossRef]

50. Sack, L.; Frole, K. Leaf structural diversity is related to hydraulic capacity in tropical rain forest trees. Ecology 2006, 87, 483-491. [CrossRef] 
51. Thomas, N.B.; Grace, P.J.; Scoffoni, C.; Sack, L. How does leaf anatomy influence water transport outside the xylem? Plant Physiol. 2015, 168, 1616-1635.

52. Scoffoni, C.; Rawls, M.; McKown, A.; Cochard, H.; Sack, L. Decline of Leaf Hydraulic Conductance with Dehydration: Relationship to Leaf Size and Venation Architecture. Plant Physiol. 2011, 156, 832-843. [CrossRef]

53. Ishida, A.; Nakano, T.; Yazaki, K.; Matsuki, S.; Koike, N.; Lauenstein, D.; Shimizu, M.; Yamashita, N. Coordination between leaf and stem traits related to leaf carbon gain and hydraulics across 32 drought-tolerant angiosperms. Oecologia 2008, 156, 193-202. [CrossRef]

54. Khansaritoreh, E.; Schuldt, B.; Dulamsuren, C. Hydraulic traits and tree-ring width in Larix sibirica Ledeb. as affected by summer drought and forest fragmentation in the Mongolian forest steppe. Ann. For. Sci. 2018, 75, 30. [CrossRef]

55. Gould, P.J.; Harrington, C.A. Extending sapwood-Leaf area relationships from stems to roots in Coast Douglas-fir. Ann. For. Sci. 2008, 65, 802. [CrossRef]

56. Simonin, K.; Kolb, T.E.; Montes-Helu, M.; Koch, G.W. Restoration thinning and influence of tree size and leaf area to sapwood area ratio on water relations of Pinus ponderosa. Tree Physiol. 2006, 26, 493-503. [CrossRef] [PubMed]

57. Togashi, H.F.; Prentice, I.C.; Evans, B.J.; Forrester, D.I.; Drake, P.; Feikema, P.; Brooksbank, K.; Eamus, D.; Taylor, D. Morphological and moisture availability controls of the leaf area-to-sapwood area ratio: Analysis of measurements on Australian trees. Ecol. Evol. 2015, 5, 1263-1270. [CrossRef] [PubMed]

58. Bartlett, M.K.; Scoffoni, C.; Sack, L. The determinants of leaf turgor loss point and prediction of drought tolerance of species and biomes: A global meta-analysis. Ecol. Lett. 2012, 15, 393-405. [CrossRef] [PubMed]

59. Poorter, L.; Bongers, F. Leaf traits are good predictors of plant performance across 53 rain forest species. Ecology 2006, 87, 1733-1743. [CrossRef]

60. Sterck, F.J.; Poorter, L.; Schieving, F. Leaf traits determine the growth-survival trade-off across rain forest tree species. Am. Nat. 2006, 167, 758-765.

61. Wright, S.J.; Kitajima, K.; Kraft, N.J.B.; Reich, P.B.; Wright, I.J.; Bunker, D.E.; Condit, R.; Dalling, J.W.; Davies, S.J.; Díaz, S.; et al. Functional traits and the growth-mortality trade-off in tropical trees. Ecology 2010, 91, 3664-3674. [CrossRef]

62. Sinclair, T.R.; Zwieniecki, M.A.; Holbrook, N.M. Low leaf hydraulic conductance associated with drought tolerance in soybean. Physiol. Plantarum. 2008, 132, 446-451. [CrossRef] [PubMed] 